\title{
Assessment of the physicochemical parameters and heavy metals toxicity of leachates from municipal solid waste open dumpsite
}

\author{
${ }^{1}$ O. O. Ogundiran; ${ }^{2 *}$ T. A. Afolabi \\ ${ }^{1}$ Department of Petroleum and Chemical Science, Tai Solarin University of Education, Ijebu-Ode, Nigeria \\ ${ }^{2}$ Department of Chemistry, University of Ado-Ekiti, Ado-Ekiti, Nigeria, and a Ph.D. Research Student in Industrial \\ Chemistry at the University of Ibadan, Ibadan, Nigeria
}

Received 4 November 2007; revised 28 December 2007; accepted 12 February 2008; available online 10 March 2008

\begin{abstract}
Heavy metals and physicochemical characteristics of the different sites of the municipal solid waste dumpsite at Olusosun Landfill, Lagos, Nigeria, were investigated. The dormant site of the landfill has the potential of being a source of immediate environmental risk compared to the active and abandoned site, with the active site exhibiting tendency to be a likely source of $\mathrm{Pb}, \mathrm{Cd}$ and $\mathrm{Zn}$ pollution. $\mathrm{Zn}$ was the most abundant metal in the area $(0.264-$ $0.947 \mathrm{mg} / \mathrm{L}$ ) while Cd concentration was the lowest (0.001-0.022 mg/L). Pb, Cd, Zn were from anthropogenic sources and correlated significantly with chemical oxygen demand and oil and grease. $\mathrm{Cu}$ and $\mathrm{Cr}$ were more abundant in the dormant site and are attached to the solids as indicated by their significant correlation with TS and SS. The physicochemical characteristic of the leachate from the landfill indicate that they were more alkaline in nature, with TA range of 2354 to $7946 \mathrm{mg} / \mathrm{L}$ while the chemical oxygen demand values was also high 518.14 to $725.01 \mathrm{mg} / \mathrm{L}$. The comparative analysis of the dormant site with other dormant site reveal a moderate concentration of the parameters measured but could contaminate the neighboring groundwater if not checked.
\end{abstract}

Key words: Landfill, pollution, dumpsite, environmental hazard, dormant site, active site

\section{INTRODUCTION}

Human existence on earth is almost impossible without chemicals. Chemicals and their products are very important to mankind due to the benefits they accrue. However, exposure to them during production, usage and their uncontrolled discharge into the environment has caused lots of hazards to man, other organisms and the environment itself. Over 100,000 of chemicals used by man are maintained in the ecosystem and several of these have been reported to exhibit toxic effects on lives (Nowierski et al., 2006; Herrera-Silveira et al.; 2004; Malallah et al., 1998; Parsons et al., 1984). Consequently, the management of our environment and the control of discharge of waste products from anthropogenic activities is of high interest to researchers, regulatory bodies, environmental advisory agencies and policy-makers all over the world. Rapid urbanization, industrialization and population growth have been the major causes of stress on the environment leading to problems like human health problems, eutrophication and fish death, coral reef destruction, biodiversity loss, ozone layer depletion

\*Corresponding Author Email: niyiafo@yahoo.com

Tel./Fax: +23 48035718657 and climatic changes (Bay et al., 2003; Sadiq, 2002). Determination of adverse effects of various elements upon human health and the ecosystem has been gaining momentum recently, especially on scientific, social and emotional ground. Hence, there is a presumption that sound scientific data base is needed to define maximum exposure levels of specific chemical compound(s) of health implications (Fortner and Wittman, 1983). The Olusosun landfill, located in Lagos-State, the industrial and commercial centre of Nigeria with a population of over 10 million people is one of the major deposits of both domestic and industrial waste from the state. These waste products are dumped in this landfill untreated, posing environmental risks to life in the area and the entire population directly or indirectly. Landfill is a practice adopted as a substitute to ocean outfall of sewage, domestic and industrial waste, after the outlawing and termination of the latter due to its effects on the lives in the ocean. The ocean outfall causes introduction of pollutants into the food-web through bioaccumulation, changes in the biotic diversity and introduction of persistent organic compounds (like PAHs) into the marine environment. However, with the 
termination of ocean outfall, especially in USA in 1992, as a result of Ocean Disposal Ban Act of 1988 (Adriano, 2001; De Zuane, 1990) and in the European Union under the Urban Waste Water Treatment Directive (European Union, 2000), there has been a growing concern on the environmental safety of landfill application of waste products, such as long term build-up of heavy metals in the soil, effects on groundwater and pathogenic effects (Zherg et al., 1991; Parson et al., 2004; Karrasch et al., 2006; Cheng et al., 2004). The heavy metals investigated in this study have been implicated for various human health problems even at trace levels. The analyzed standard samples show recovery values ranging from 88-93\% of the prepared standard. Lead has been implicated in various disease such as anaemia, brain damage, anorexia, mental deficiency, vomiting and even death in human (Maddock and Taylor, 1977; Bulut and Baysal, 2006; Low et al., 2000). Cadmium also has been reported to cause agonistic and antagonistic effects on hormones and enzymes leading to lots of malformations like renal damage (Lewis, 1991; Donalson, 1980). These two metals have affinity for $\mathrm{SH}$ groups in proteins, haemoglobin, enzymes/ hormones (Manahan, 1992). Likewise, Pb and Cd are classified as carcinogens (USEPA 1999; Pekey, 2006). Other metals, investigated in this study, were $\mathrm{Ni}, \mathrm{Cr}$, $\mathrm{Zn}$ and $\mathrm{Cu}$, each of which has been reported for various health problems being non-biodegradable and with the possibility of accumulation in the food web (Langston, 1990). This study is conducted on leachates from the municipal solid waste dumpsite at Olusosun Landfill, near Ojota area, Lagos, Nigeria, to assess its heavy metal build-up.

\section{MATERIALS AND METHODS}

The leachates from Olusosun landfill were used for the study. Physicochemical characteristics like chemical oxygen demand (COD), alkalinity, solids, oil and grease were determined. The choice of the leachate was based on the view that leachates in landfills ultimately leak, percolate and contaminate the groundwater; hence, its analysis can be an indication of environmental pollution. The landfill site is in about Lat. $6^{\circ} 20^{\prime} \mathrm{N}$ and Long. $3^{\circ} 20^{\prime}$ E, Ojota area of Lagos state, Nigeria (Fig. 1). The dumpsite has been in existence since 1978 and receives over 25,000 tons of waste per annum (Lagos Waste Disposal Board, 2006). It is a few kilometres away from the Lagos lagoon and Bright of Benin. The landfill is surrounded by some industrial factories, a gasoline station, a motor park, an automobile repair workshop and road network are all sources of waste and pollution discharge in addition to the transported waste discharge into the fill. The wastes deposited in the landfill are predominately solid wastes from both industrial and domestic sources. The samples for this study were taken from 5 sampling points across the landfill that is about 6 ha in area. At each sampling point, the temperature and $\mathrm{pH}$ were measured immediately while another sample was taken for metals, oil, grease and physicochemical properties. The landfill is best categorized into three groups: the active site where waste dumping is still actively practised, the dormant site with passive or withdrawn waste dumping and the abandoned site where the dumping has been stopped for a long time. The active site is labelled $A$ while the abandoned and the dormant sites are labelled $B$ and $C$, respectively as shown in Fig. 1 (III). The sample containers (high density polyethylene-HDPE bottles), used to sample for heavy metal analysis, were washed with metal free detergent and rinsed with tap water. They were soaked in $1 \mathrm{M} \mathrm{HNO}_{3}$ for $24 \mathrm{~h}$ and later rinsed with demineralised water and kept in air-tight container till sampling period. Glass containers were used for the determination of oil and grease. These glass containers were washed with detergent and tap water, soaked in $1 \mathrm{M} \mathrm{HNO}_{3}$ for $24 \mathrm{~h}$ and rinsed with distilled water. It was later rinsed with acetone, dried at $110^{\circ} \mathrm{C}$ and kept in air-tight container till the sampling period. All samplings were obtained as composite mixtures from different points at each site for proper representation. The sampling bottles were first rinsed with the leachate before sampling. The samples collected for heavy metals were preserved by the addition of concentrated $\mathrm{HNO}_{3}(1 \mathrm{~mL}$ per litre of leachate sample). This is to adjust the $\mathrm{pH}$ of the sample to less than 2, so as to arrest microbial activities and prevent loss of the metals by precipitation and adsorption. All samples collected were kept in ice chest to maintain them at a temperature below $4{ }^{\circ} \mathrm{C}$ during transference from the field to the laboratory. They were also kept in refrigerator under the laboratory condition till analyses were completed on them. The time between sampling and analyses of samples was kept short and between recommended times by the standard method. To avoid contamination, the nitric acid used in preservation was ultra pure grade (J. T. Baker, Ultrex).

The methods of analysis were adopted for all parameters and were used for the examination of water 


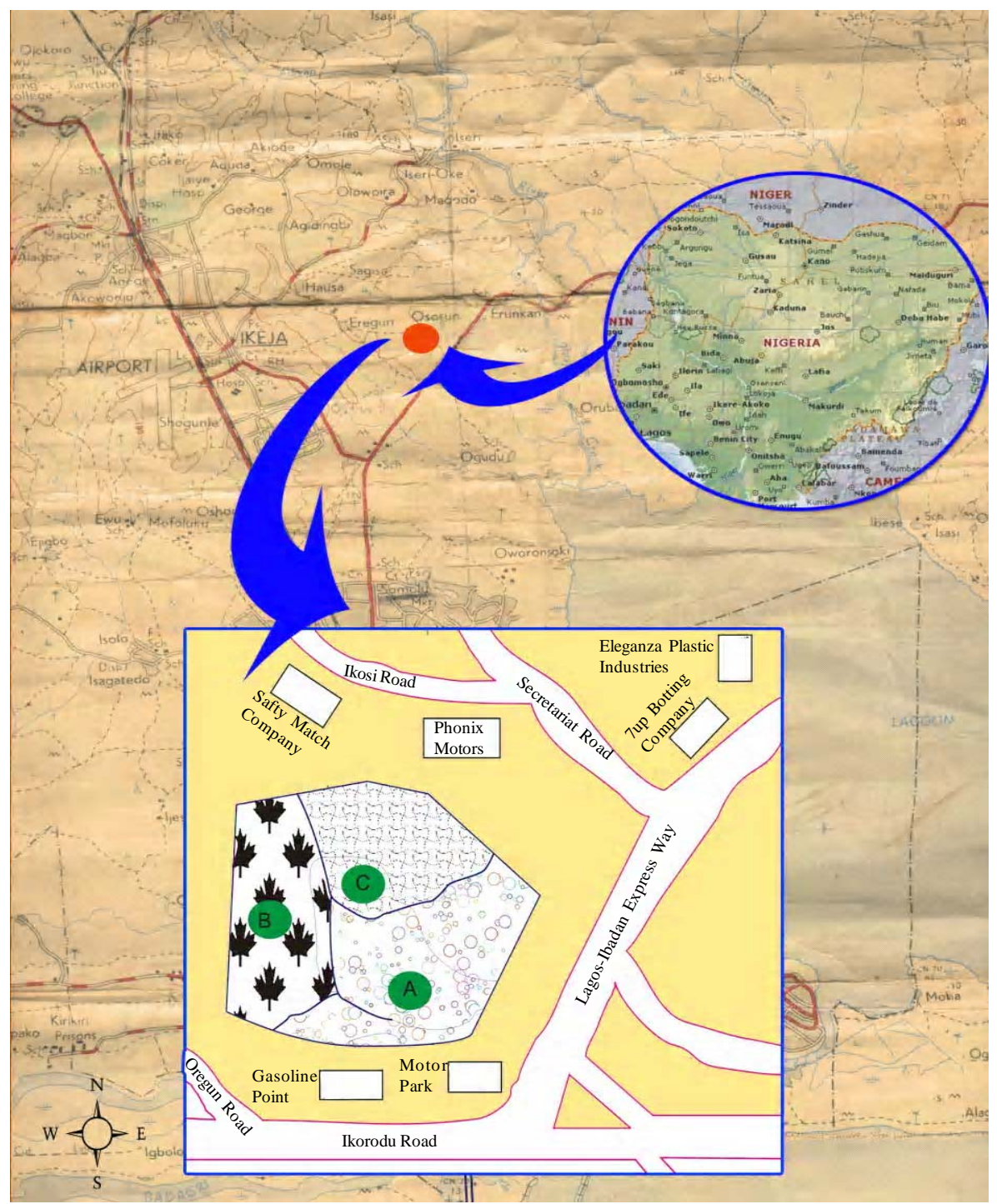

Fig. 1: Map and schematic diagram of the sampling site of Olusosun landfill A: Active site, B: Abandoned site, C: Dormant site

and wastewater as recommended by the standard method (APHA, 1995). The metal analysis were done by the digestion of $50 \mathrm{~mL}$ of the sample using concentrated nitric acid to release the organic bound metals and those in particulate or those adsorbed on particulates. The digested samples were analyzed in duplicate, using a Buck Scientific Flame Atomic Absorption Spectrophotometer Model 205. A blank was also analyzed and the results were less than $5 \%$ of each metal determined in samples. The quality control of the method was determined by the analysis of a known standard sample prepared from the metals in demineralized distilled water and subjected to the same process as the sample, so as to determine accuracy and precision of the method used. Three replicate analysis was done for all of the metals and the relative standard deviation was between 8 to $14 \%$. COD was determined through using potassium dichromate in an open reflux method. Mercuric sulphate was used to mask chloride interference and silver sulphate dissolved in concentrated $\mathrm{H}_{2} \mathrm{SO}_{4}$ and was used as catalyst. All of the used reagents were analytical grade. The excess dichromate after a $2 \mathrm{~h}$ reflux was titrated with standardized ferrous ammonium sulphate (FAS) and ferroin indicator. 
The total alkalinity was measured by the titration of the leachate sample with $0.1 \mathrm{~N} \mathrm{H}_{2} \mathrm{SO}_{4}$. Phenolphthalein indicator was first added but no color change was observed implying that the leachates have no phenolphthalein alkalinity. Afterwards, the titration was done using methyl orange. The total alkalinity was measured as $\mathrm{mgCaCO}_{3} / \mathrm{L}$ based on the volume of acid consumed by the leachate samples. Finally, the solids (total solid and suspended solid) were determined by gravimetric method (APHA, 1995). The data obtained from the chemical analysis were subjected to descriptive statistical analysis (mean, range and standard error of mean at 95\% confident limit). The general linearized model (GLM) of SAS was used to generate analysis of variance (ANOVA), means, standard error and range. Correlation and regression analysis was performed using Proc Corr and Proc Reg procedures of SAS (SAS, 2000).

\section{RESULTS AND DISCUSSION}

The result of physicochemical properties of the leachate samples is presented in Table 1 . The analysis of the samples collected reveals some level of compliance with regulated standards and the significant deviations were equally noticed. The mean $\mathrm{pH}$ of the whole landfill was 7.88 while its $\mathrm{pH}$ ranged from 7.01 to 8.22 which falls within the WHO regulated value. The dormant site has the highest $\mathrm{pH}$ which is at par with others reported in the literature (Abu-Rukah and Al-Kafahi, 2001; Keimowitz, 2005; Futta et al., 1997). This is in agreement with the postulate that the $\mathrm{pH}$ of leachate increases with landfill age (Futta et al., 1997) although a deviation was noticed at the abandoned site. This is probably due to the fact that leachates have, to a large extent, witnessed washing-away by rainfall or percolated over time into the soil. Oygard et al. (2007) also observed that the heavy metals leached from the landfill are usually found in the form of free cation, dissolved organic compound complex, particulate and colloid. Most of these heavy metals from the surface layer of an open dumpsite usually creeps into the bottom layer of the dumpsite where anaerobic condition prevails (He et al., 2006; Bozkurt et al., 2000; Matensson et al., 1999; Flyhammar, 1998). The trend observed in the determination of solids shows that the dormant site poses more environmental risks at the immediate than any other site. The dormant site has a mean total solids (TS) value of $120.77 \mathrm{mg} / \mathrm{L}$ and mean suspended solids (SS) value, i.e. $42.41 \mathrm{mg} / \mathrm{L}$, compared to the active and abandoned site with TS of $7.9 \mathrm{mg} / \mathrm{L}, 6.69 \mathrm{mg} / \mathrm{L}$ and SS of $5.16 \mathrm{mg} / \mathrm{L}$ and $2.31 \mathrm{mg} / \mathrm{L}$, respectively. This result implies that the dormant site is possibly undergoing biodegradation which is increasing the solids, while the abandoned site has already been degraded and leached away. However, the waste of the active site is still fresh and possibly not undergoing degradation. This view was further supported by the results of the COD and oil and grease of the sites in the landfill. The landfill, being a solid waste one with more of organic matter from anthropogenic sources, show a mean of the COD values in the order of $518.14 \mathrm{mgO}_{2} / \mathrm{L}$ (abandoned site) less than $598.81 \mathrm{mgO}_{2} / \mathrm{L}$ (dormant site) and $725.01 \mathrm{mgO}_{2} / \mathrm{L}$ (active site). This strongly upholds the view that the active site is less degraded while the dormant site is biodegrading and the abandoned one is much degraded, and thus having lesser organic matters. This is in agreement with the observation of Xiaoli et al. (2007) that most organic chemical substances are either degraded through biochemical reactions in the landfill, or leached out from the landfill with water movement. The oil and grease analysis result also follow the trend of COD (Table 1). The total alkalinity (TA) observed in the dormant site was high (7946 $\left.\mathrm{mgCaCO}_{3} / \mathrm{L}\right)$ above the Nigerian Federal Environmental Protection Agency (FEPA) permitted standard of 30-500 $\mathrm{mg} \mathrm{CaCO}_{3} / \mathrm{L}$ (Lagos Waste Disposal Board, 2006).

Table 1: Physicochemical properties of leachates of Olusosun landfill ${ }^{*}$

\begin{tabular}{lllll}
\hline Sites parameters & Active site & Abandoned site & Dormant site & $\begin{array}{l}\text { Mean value } \\
\text { (Whole landfill) }\end{array}$ \\
\hline pH & $7.96 \pm 0.03$ & $7.58 \pm 0.81$ & $8.10 \pm 0.17$ & $7.88 \pm 0.25$ \\
Temp $\left({ }^{\circ} \mathrm{C}\right)$ & $26.50 \pm 0.00$ & $26.65 \pm 0.21$ & $26.75 \pm 0.36$ & $26.63 \pm 0.12$ \\
TS & $7.19 \pm 2.70$ & $6.69 \pm 3.41$ & $120.77 \pm 13.14$ & $44.88 \pm 61.96$ \\
SS & $5.16 \pm 3.14$ & $2.31 \pm 0.52$ & $42.41 \pm 32.51$ & $16.63 \pm 21.1$ \\
TA & $2943 \pm 8.50$ & $2354 \pm 6.36$ & $7946 \pm 4.44$ & $4414.33 \pm 6.93$ \\
Oil and Grease & $0.77 \pm 0.05$ & $0.40 \pm 0.00$ & $0.52 \pm 0.03$ & $0.56 \pm 0.18$ \\
COD & $725.01 \pm 25.00$ & $518.14 \pm 23.21$ & $598.81 \pm 31.25$ & $613.99 \pm 38.30$ \\
\hline
\end{tabular}

*Results are means of triplicate determination \pm standard deviations (SD) 
Int. J. Environ. Sci. Tech., 5 (2), 243-250, Spring 2008

Table 2: Correlation coefficient of parameters

\begin{tabular}{|c|c|c|c|c|c|c|c|c|c|c|c|c|}
\hline & $\mathrm{pH}$ & Temp & TS & SS & TA & $\begin{array}{l}\text { Oil and } \\
\text { Grease }\end{array}$ & COD & $\mathrm{Pb}$ & $\mathrm{Cd}$ & $\mathrm{Ni}$ & $\mathrm{Cr}$ & $\mathrm{Zn}$ \\
\hline \multicolumn{13}{|l|}{$\mathrm{pH}$} \\
\hline Temp & -0.02 & & & & & & & & & & & \\
\hline TS & 0.71 & 0.69 & & & & & & & & & & \\
\hline SS & 0.75 & 0.65 & 1.00 & & & & & & & & & \\
\hline $\begin{array}{l}\text { TA } \\
\text { Oil and }\end{array}$ & 0.77 & 0.62 & 1.00 & 1.00 & & & & & & & & \\
\hline Grease & 0.55 & -0.84 & -0.20 & -0.14 & -0.10 & & & & & & & \\
\hline COD & 0.61 & -0.80 & -0.12 & -0.06 & -0.03 & 1.00 & & & & & & \\
\hline $\mathrm{Pb}$ & -0.07 & -1.00 & -0.75 & -0.71 & -0.69 & 0.79 & 0.74 & & & & & \\
\hline $\mathrm{Cd}$ & 0.20 & -0.98 & -0.55 & -0.50 & -0.47 & 0.93 & 0.90 & 0.96 & & & & \\
\hline $\mathrm{Ni}$ & -0.74 & 0.68 & -0.06 & -0.12 & -0.15 & -0.97 & -0.98 & -0.61 & -0.80 & & & \\
\hline $\mathrm{Cr}$ & 0.93 & 0.35 & 0.92 & 0.94 & 0.95 & 0.21 & 0.28 & -0.43 & -0.18 & -0.44 & & \\
\hline Zn & -0.03 & -1.00 & -0.73 & -0.68 & -0.66 & 0.82 & 0.77 & 1.00 & 0.97 & -0.65 & -0.40 & \\
\hline $\mathrm{Cu}$ & 0.60 & 0.79 & 0.99 & 0.98 & 0.97 & -0.34 & -0.27 & -0.84 & -0.67 & 0.09 & 0.85 & -0.82 \\
\hline
\end{tabular}

Table 3: Comparison of Olusosun dormant site with other dormant sites parameters

\begin{tabular}{|c|c|c|c|c|c|c|}
\hline Sites parameters & $\begin{array}{l}\text { El-Akader, } \\
\text { Jordan }^{\text {a }}\end{array}$ & $\begin{array}{l}\text { Gronomo, } \\
\text { Norway }\end{array}$ & $\begin{array}{l}\text { Cedar Hill, } \\
\text { USA }^{\text {b }}\end{array}$ & $\begin{array}{l}\text { Kent Highlands, } \\
\text { USA }^{\text {b }}\end{array}$ & $\begin{array}{l}\text { Taranrod, } \\
\text { Japan }^{\text {c }}\end{array}$ & $\begin{array}{l}\text { Olusosun, } \\
\text { Nigeria }^{\mathrm{d}}\end{array}$ \\
\hline $\mathrm{pH}$ & 7.79 & 6.80 & 5.40 & 6.40 & 6.20 & 8.1 \\
\hline Temp & 20 & NA & NA & NA & NA & 26.75 \\
\hline TS (mg/L) & NA & 2960 & NA & NA & 3160 & 120.77 \\
\hline SS (mg/L) & NA & 140 & 310 & 230 & 1079 & 42.41 \\
\hline $\mathrm{TA}\left(\mathrm{mgCaCO}_{3} / \mathrm{L}\right)$ & 670 & 41 & 130 & 26 & 21.6 & 7946 \\
\hline Oil and Grease (mg/L) & NA & NA & NA & NA & NA & 0.52 \\
\hline $\mathrm{COD}\left(\mathrm{mgO}_{2} / \mathrm{L}\right)$ & NA & 470 & 38,800 & 3,800 & 3,455 & 598.81 \\
\hline $\mathrm{Pb}(\mathrm{mg} / \mathrm{L})$ & 0.190 & 0.004 & 1.40 & 20.10 & 0.015 & 0.110 \\
\hline Cd (mg/L) & 0.012 & 0.005 & ND & ND & 0.033 & 0.001 \\
\hline $\mathrm{Ni}(\mathrm{mg} / \mathrm{L})$ & 18 & $<0.100$ & 1.200 & 0.100 & 0.120 & 0.070 \\
\hline Cr (mg/L) & NA & 0.023 & 10.50 & 0.050 & 0.170 & 0.060 \\
\hline Zn (mg/L) & 95 & 0.055 & 155.00 & 5.300 & 2.650 & 0.264 \\
\hline $\mathrm{Cu}(\mathrm{mg} / \mathrm{L})$ & 0.21 & 0.085 & 1.300 & 0.180 & 0.021 & 0.200 \\
\hline
\end{tabular}

${ }^{a}$ Abu-Rukah and Al-Kafahi (2001), ${ }^{\text {b }}$ Hovarth (1988), ${ }^{c}$ Jeffery et al. (1989), ${ }^{\text {d }}$ This study

NA: Not available, ND: Not detectable. The results are means of triplicate determinations.

The TA results of the other sites were also beyond the regulated level but lower than that of the dormant site. A comparison of the Olusosun landfill's dormant site was done with that of global landfills reported in the literature (Table 3) to assess the potential health risk posed by the dormant site. The parameters used in this study were found to be moderate or lower compared to other landfills. With the exception of the $\mathrm{pH}$ (8.1) and the alkalinity $\left(7946 \mathrm{mgCaCO}_{3} / \mathrm{L}\right)$, all other parameters were lower than what was obtainable in other landfill studied (Table 3). This may be due to the nature of waste disposed into the landfill, the rate of leaking or rainfall index and the age of it. The correlation coefficient between the parameters investigated (Table 2) further shows that there was a very high correlation between the solids, and between them and TA, indicating that the solids in the leachates was possibly alkaline. The significant correlation of the $\mathrm{pH}$ with TS, SS and TA ( $\mathrm{r}$ $=0.71,0.75,0.77$ at $\mathrm{p}<0.05$, respectively) supports this view. COD, oil and grease were significantly related ( $\mathrm{r}$ $=1.00, \mathrm{p}<0.05$ ), being both from anthropogenic sources and measure of organic matter. However, the solids and TA show no relationship with COD and oil and grease (Table 2). 


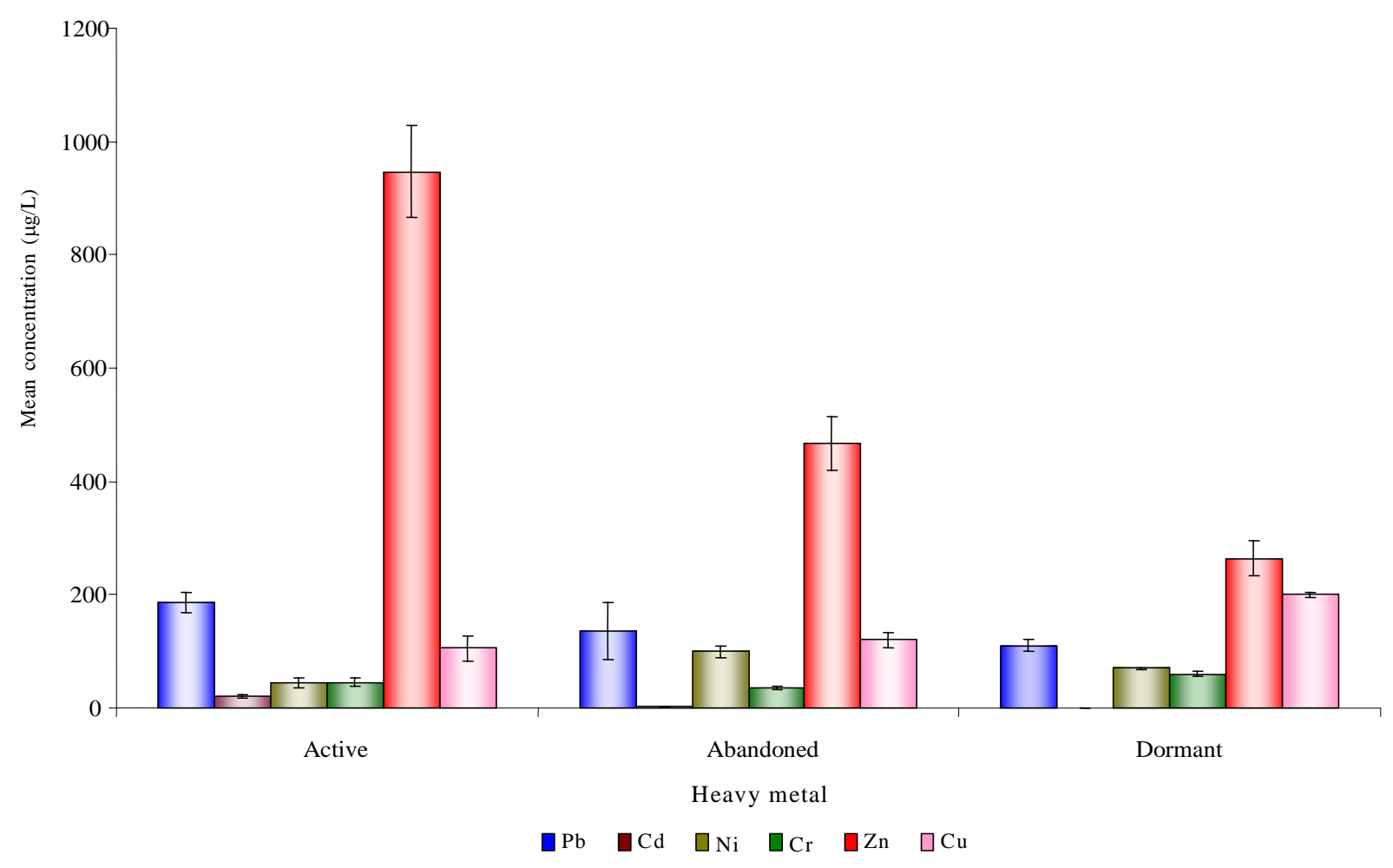

Fig. 2: Mean values of heavy metals in the leachate samples of Olusosun landfill, Lagos

The results of the heavy metal investigation in the landfill (Fig. 2) show Zn to be the most predominant metal in the landfill $(0.264-0.947 \mathrm{mg} / \mathrm{L})$, while Cd concentration was the lowest (0.001-0.022 mg/L). Only $\mathrm{Ni}$ was found abundant at the abandoned site. The concentration of $\mathrm{Pb}, \mathrm{Cd}$ and $\mathrm{Zn}$ in the active site was the highest compared with other sites, indicating that the active site could be a possible source of these metals' poisoning if not controlled or treated, since the metals are not biodegradable. In addition, $\mathrm{Pb}, \mathrm{Cd}$ and $\mathrm{Zn}$ are from anthropogenic sources because of their high correlation with measures of organic matter (COD and oil and grease) and their high correlation with each other (Table 2). Moreover, $\mathrm{Cu}$ and $\mathrm{Cr}$ were more abundant in the dormant site and are likely to be attached to the solids as indicated by their significant correlation with TS and SS (Table 2). This established further the indications of the possibility that the dormant site poses an immediate health risk.

The physicochemical characterization of the leachate from Olusosun landfill indicate that the leachate is alkaline in nature and has high COD value with potential effect on the environment and neighboring groundwater. The dormant site was found to pose immediate health risk through various parameters measured though some were moderate. The active site, however, was a potential source of $\mathrm{Pb}, \mathrm{Cd}$ and $\mathrm{Zn}$ poison and a source of pollution to the environment if the present trend of indiscriminate disposal of waste on the site is not controlled. A waste management and treatment policy should be put in place for the landfill and waste disposal must be controlled by pre-treatment before disposal. Finally, the comparison of the metals in the landfill were within WHO and FEPA standards, except for $\mathrm{Pb}$ and $\mathrm{Cr}$ that were fairly higher; hence, control measure should be established to manage the state of the landfill.

\section{ACKNOWLEDGEMENT}

The authors would like to acknowledge the service of Mr. Basil of the Analytical Service Laboratuary, International Institute of Tropical Agriculture (IITA), Ibadan, Nigeria, for the running of the AAS for metal analysis. 


\section{REFERENCES}

Abu-Rukah, Y.; Al-Kafahi, O., (2001). The assessment of the effect of landfill leachate on groundwater quality - a case study. El-Akader landfill site - North Jordan. J. Arid Environ., 49 (3), 615 - 630.

Adriano D. C., (2001). Trace elements in terrestrial environments. $2^{\text {nd. }}$ Ed. New York: Springer-Verlag. 87 - 92.

APHA (1995). Standard method for examination of water and wastewater, American Public Health Association. 23-89.

Bay, S. M.; Zeng, E. Y.; Lorenson, T. D.; Tran, K.; Alexander, C., (2003). Temporal and spatial distributions of contaminants in sediments of Santa Monica Bay, California. Mar. Environ. Res., 56 (1-2), 255 - 276.

Bozkurt S.; Moreno L.; Neretnieks I., (2000). Long-term processes in waste deposits, Sci. Total Environ., 250 (1-3), 101-121.

Bulut, Y.; Baysal, Z., (2006). Removal of Pb (II) from wastewater using wheat bran. J. Environ. Manage., 4, 7889.

Cheng Z.; Zheng Y.; Mortlock R.; van Geen A., (2004). Rapid multi-element analysis of groundwater by high-resolution inductively coupled plasma mass spectrometry. Anal. Bioanal. Chem., 379 (3), 512-8.

De Zuane, J., (1990). Handbook of drinking water quality: standards and control. New York, NY: Van Nostrand Reinhold, $33-69$.

Donalson, W. E., (1980). Trace element toxicity, In: Introduction to Biochemical Toxicology, Ernest Hodgson \& Frank E. Guthrie Eds, Elsevier, New York, 330 - 340.

European Union, (2000). Directive of the European Parliament and of the Council 2000/60/EC establishing a framework for community action in the field of water policy. PE-CONS 3639/1/00 Rev 1.

Flyhammar, P., (1998). Use of sequential extraction on anaerobically degraded municipal solid waste, Sci. Total Environ., 212 (2-3), 203-215.

Fortner, U.; Wittman, G. T (1983). Metal Pollution in the aquatic environment. Heidelberg: Springer Verlag Berlin, 489.

Futta, D.; Yoscos, C.; Haralambous, K. J.; Loizidou, M., (1997). An assessment of the effect of landfill leachate on groundwater quality. Proceeding Sardina 97. $6^{\text {th. }}$ Int. landfill symposium S. Margheria di Pule, Gagliari, Italy. 181 - 187.

He, P. J.; Xiao, Z.; Shao, L. M.; Yu, J. Y.; Lee, D. J., (2006). In situ distribution and characteristics of heavy metals in fullscale landfill layers, J. Hazard. Mater., 137 (3), 1385-1394.

Herrera-Silveira, J. A.; Comin, F. A.; Aranda-Cirerol, N.; Troccoli, L.; Capurro, L., (2004). Coastal water quality assessment in the Yucatan Peninsula: management implications. Ocean, Coas. Manage., 47 (11-12), 625 639.

Karrasch, B.; Parra, O.; Cid, H.; Mehrens, M.; Pacheco, P.; Urrutia, R.; Valdovinos, C.; Zaror, C., (2006). Effects of pulp and paper mill effluents on the microplankton and microbial self-purification capabilities of the Biobýo River, Chile. Sci.Total Environ., 359 (1-3), 194- 208.

Keimowitz, A. R.; Zheng, Y.; Chillrud, S. N.; Mailloux, B.; Jung, H. B.; Stute, M., (2005). Arsenic redistribution between sediments and water near a highly contaminated source. Environ. Sci. Technol., 39(22), 86, 06-13.
LWDB, (2006). Organization development and waste management system project, Lagos Waste Disposal Board. Assessment report, 1, $1-5$.

Langston, W., (1990). Toxic effects of metals and the incidence of metal pollution in marine coastal ecosystem. In R. W. Furness; P. S. Rainbow (Eds.). Heavy metals in the marine environment, Boca Raton: CRC Press Inc. 101 122.

Lewis, R. J., (1991). Hazardous chemicals desk reference 2nd eds, Van Nostrand Reinhold, New York, USA, 1 - 71.

Low, K. S.; Lee, G. K.; Liew, S. C., (2000). Sorption of cadmium and lead from aqueous solutions by spent grain. Proc. Biochem., 36 (1), 59 - 64.

Maddock, B.G.; Taylor, D., (1977). The acute toxicity and bioaccumulation of some lead compounds in marine animals. In: Lead in the marine environment, Proceeding of the international experts discussion on lead occurrence, Fate and pollution in the marine environment, Rovinj, Yugoslavia, 18 - 22 October, 233 - 261.

Malallah, G.; Afzal, M.; Kurian, M.; Gulshan, S.; Dhami, M. S. I., (1998). Impact of oil pollution on some desert plants. Environ. Int., 24 (8), 919 - 924.

Manahan, S. E., (1992). Toxicological chemistry, $2^{\text {nd. }}$ Eds, Lewis Publisher Inc., Chelsea, Michigan, USA, 52 - 77.

Matensson, A. M.; Aulin, C.; Wahlberg, O.; Agren, S., (1999). Effect of humic substances on the mobility of toxic metal in a mature landfill, Waste Manage. Res, 17, 296-304.

Nowierski, M.; Dixon, D. G.; Borgmann, U., (2006). Lac Dufault sediment core trace metal distribution, bioavailability and toxicity to Hyalella azteca. Environ. Pollut., 139 (3), 532 - 540.

Oygard, J. K., Gjengedal, E.; Royset, O., (2007). Size charge fractionation of metals in municipal solid waste landfill leachate, Water Res., 41 (1), 47-54.

Parsons, T.; Maita, Y.; Lalli, C., (1984). A manual of chemical and biological methods for seawater analysis. Oxford Pergamon Press, 22 - 85.

Pekey, H., (2006). The distribution and sources of heavy in Izmit Bay surface sediments affected by a polluted stream. Mar. Pollut. Bull., 52 (10), 1197 - 1208.

Sadiq, M., (2002). Metal contamination in sediments from a desalination plant effluent outfall area. Sci. Total Environ., 287 (1), 37-44.

SAS Institute Inc., (2000). SAS software release 9.1. SAS Institute Inc., Cary, North Carolina, USA.

USEPA (1999). Integrated risk information system (IRIS). National centre for environmental assessment, Office of research and development, United State environmental protection agency, Washington DC.

Xiaoli, C.; Shimaoka, T.; Xianyan, C.; Qiang G.; Youcai, Z.; (2007). Characteristics and mobility of heavy metals in an MSW landfill: Implications in risk assessment and reclamation. J. Hazard. Mater., 144 (1-2), 485-491.

Zherg, C.; Bannett, G. D.; Andrew, C. B., (1991). Analysis of groundwater remedial alternatives of a super fund site. Groundwater, 29, 838-848. 


\section{AUTHOR (S) BIOSKETCHES}

Ogundiran, O. O., M.Sc., Lecturer, Department of Petroleum and Chemical Science, Tai Solarin University of Education, Ijebu-Ode, Nigeria. Email: royalink07@yahoo.co.uk

Afolabi, T. A., M.Sc., Ph.D., Lecturer, Department of Chemistry, University of Ado-Ekiti, Ado-Ekiti, Nigeria, and a Ph.D. research student in industrial chemistry at the University of Ibadan, Ibadan, Nigeria.

Email: niyiafo@yahoo.com

This article should be referenced as follows:

Ogundiran, O. O.; Afolabi, T. A., (2008). Assessment of the physicochemical parameters and heavy metals' toxicity of leachates from municipal solid waste open dumpsite. Int. J. Environ. Sci. Tech., 5 (2), 243-250. 